INDEPENDENT JOURNAL OF MANAGEMENT \& PRODUCTION (IJM\&P) http://www.ijmp.jor.br

v. 12, n. 2, March-April 2021 ISSN: 2236-269X

DOI: $10.14807 /$ ijmp.v12i2.1313

\title{
INVESTIGATING THE IMPACTS OF PERSONALITY TRAITS ON COLLABORATIVE CONSUMPTION INTENTION OF LUXURY FASHION PRODUCTS AMONG MIDDLE-AGED WOMEN
}

\author{
Christian Rodil Navia \\ International College, Taiwan \\ E-mail: croisrodilnavia@gmail.com \\ Rushikesh Ulhas Khire \\ Providence University, Taiwan \\ E-mail: rukhire@pu.edu.tw \\ Maurice Lyver \\ National Taichung University of Science and Technology, Taiwan \\ E-mail:m.lyver@nutc.edu.tw \\ Submission: 3/20/2020 \\ Revision: 5/13/2020 \\ Accept: 7/3/2020
}

\section{ABSTRACT}

Collaborative consumption (CC) refers to the shared use of products or services in order to save costs and redistribute resources in a more sustainable way among the different agents participating in sharing economies. With the rapid popularity of CC in recent years, more and more academic research has been carried out on CC, but research exploring the impact of personality traits on consumer behavior is largely limited. To our best knowledge, existing research fails to explore CC applied to the luxury apparel context. Consequently, this study aims to investigate the impact of consumer personality traits on their attitudes and intention toward CC of luxury fashion products. This study draws a framework based on the theory of planned behavior (TPB) model introducing key personality traits, particularly, materialism, fashion leadership, and need for uniqueness as CC attitude and CC intention predictors. This research uses PLSSEM technique to analyze the data collected through a questionnaire administered to middle-aged Spanish women. The results indicate that fashion leadership had a positive influence on attitude toward CC and CC intention. Secondly, we found that consumer need for uniqueness significantly influenced attitude but had no significant impact on intention. Materialism on the other hand did not display a significant relationship with either CC attitude or intention. 
INDEPENDENT JOURNAL OF MANAGEMENT \& PRODUCTION (IJM\&P)

http://www.ijmp.jor.br

v. 12, n. 2, March-April 2021

ISSN: $2236-269 X$

DOI: 10.14807/ijmp.v12i2.1313

By contrast, attitude towards CC was determined to have a strong positive influence on CC intention. We believe that the findings as well as the proposed research model can be helpful to managers when developing CC based business models and valuable to academics in developing related theories.

Keywords: Fashion leadership; Luxury apparel goods; Materialism; Need for uniqueness.

\section{INTRODUCTION}

As a result of the emergence of mobile technologies in recent years, business model innovation has proliferated and this has led to the development of novel consumption models (Hamari et al., 2016). Consumers are gradually moving away from the typical traditional consumption approach to more collaborative consumption forms where information flows in an omnidirectional manner among all market participants and where the consumer rejects outright ownership to gain product accessibility (Belk, 2014; Botsman \& Rogers, 2010; Bardhi \& Eckhardt, 2012).

Although previous research has highlighted that the shared use of resources has always existed in economies (Felson \& Spaeth, 1978; Görög, 2018; Schor \& Fitzmaurice, 2015), the term Collaborative Consumption (CC) remained an unstudied phenomenon until Felson and Spaeth (1978) introduced the term based on Hawley's (1950) theory of human ecology. Felson and Spaeth (1978, p. 614) define CC as 'those events in which one or more persons consume economic goods or services in the process of engaging in joint activities with one or more others'. With the emergence and diffusion of various technologies like the Internet, mobile telephony, and wireless networks etc. during past few decades, CC conception has evolved and become firmly technology-centered (Ertz et al., 2016). Notably, it was Botsman and Rogers (2010, p. ix-xxii) who laid the foundation for the modern view of CC in their book, What's mine is yours: How collaborative consumption is changing the way we live, in which they define CC as:

...Traditional sharing, bartering, lending, trading, renting, gifting, and swapping, redefined through technology and peer communities; [...] enabling people to realize the enormous benefits of access to products and services over ownership, and at the same time save money, space, and time; make new friends; and become active citizens once again.

Flowing from this refined definition, it is easy to recognize how CC-based business models can be applied in various situations. To date, the most obvious and recurring examples are limited to car-sharing and house-sharing varieties, however, their implementation is rapidly expanding into more disparate businesses. The number of areas where the implementation of 
INDEPENDENT JOURNAL OF MANAGEMENT \& PRODUCTION (IJM\&P)

http://www.ijmp.jor.br

v. 12, n. 2, March-April 2021

ISSN: 2236-269X

DOI: $10.14807 /$ ijmp.v12i2.1313

the CC model is gradually growing includes industries that until just a few years ago followed the traditional consumption model based on the transfer of ownership.

This is exactly the current situation in the apparel industry. Very recently, the apparel industry has experienced the emergence of e-commerce platforms that employ a CC business model based on renting or swapping. Some popular examples of this include Casstle, Wardrobe and Rent the Runway. According to Benoit et al. (2017), CC aims to reduce the risk derived from high costs or high liabilities. Nevertheless, most of these rental platforms are currently oriented towards accessible fashion and are not specific to luxury apparel.

There have been many previous studies that focus on the causes, consequences and nature of applying the CC model in certain other industries, such as transportation Bardhi and Eckhardt (2012), Hwang and Griffiths (2017), and Schaefers et al. (2015) and tourism Amaro and Andreu (2019), Palos-Sánchez and Correia (2018), So et al. (2018) and Tussyadiah (2015). Previous research has also examined several other aspects of CC such as consumer motivations, challenges, perceived benefits, and customer loyalty (Barnes \& Mattsson, 2016; Böcker \& Meelen, 2017; Kim Et Al., 2015; Santoso \& Erdaka, 2015).

Moreover, a few recent studies such as Lang and Armstrong (2018) have investigated the interrelationship between consumer personality traits and their intention to rent/swap clothing among 431 US consumers. However, the current academic literature on sharing economies in the apparel industry is very limited and to date no empirical research has been published (to our knowledge) exploring personality traits and sharing economies within the luxury apparel industry.

Personality traits according to Lang and Armstrong (2018), are simply the inner characteristics of an individual that distinguishes them from others. Previous research indicates that personality traits affect consumer decision making in consuming particular products and services (Raja \& Malik, 2014; Lang \& Armstrong, 2015). Therefore, investigating impacts of personality traits on consumer behavior, especially in the context of novel CC based business models, is critical for research. This study attempts to fill this gap in the literature by investigating the impacts of consumer personality traits on consumer attitudes and intention towards CC of luxury apparel products.

Prior research indicates that the middle-aged population in general possesses characteristics of both the younger and older age groups because they are influenced by younger generations as well as the values and morals of their parents and the older population 
DOI: 10.14807/ijmp.v12i2.1313

(Gbadamosi, 2013). Middle-aged women have always been one of the key consumer segments of luxury products despite the fact that today's luxury brands also target younger women in the age range of 20-30 (Saxena, 2009).

According to Gbadamosi (2013), consumer needs and preferences typically change with age, thus it is very likely that the impact of personality traits on consumer decision making among middle-aged women may differ from the rest of the population. Hence, it is worthwhile to investigate the impacts of personality traits on their CC behavior. This leads to the main objective of this research, namely to investigate the impacts of middle-aged women's personality traits on their attitudes and intention toward CC of luxury apparel goods.

In order to achieve this research goal, this study proposes a research model on the basis of previous relevant research (Lang \& Armstrong, 2015). Data was collected from 123 Spanish middle-aged women via a questionnaire survey and then analyzed with PLS-SEM approach to assess the proposed hypotheses. Our results show fashion leadership and need for uniqueness to be the most influential personality traits affecting middle-aged women's behavior toward CC of luxury apparel goods.

This current study has a few contributions. First, it expands the boundaries of current literature by investigating the influence of personality traits on CC behavior in the context of luxury apparel. Second, this study focuses on middle-aged females given their importance to the luxury apparel market. Finally, this research contributes to the literature by providing managers insights into middle-aged women's personality traits and subsequent decision making considerations.

\section{LITERATURE REVIEW AND CONCEPTUAL DEVELOPMENT}

\subsection{Collaborative consumption applied to luxury apparel}

CC based business models are rapidly proliferating all over the world, especially in North America and Western Europe. CC business models generally take the form of swapping (e.g., Wardrobe, Listia or Swooped), renting (e.g., CaaStle, Rent the Runway, Gwynnie Bee, Nuuly, Bag Romance, Switch, Girl meets Dress, Panoply, L'escachotieres, Un robe une soir, Sac de Luxe, Chic by Choice or Ouh la lá) or second hand markets (e.g., Wallapop, Vinted, Letgo or Chicfy).

Despite the high profile nature of the luxury fashion industry and its significance in terms of revenues and turnovers, as well as the overconsumption behaviors and waste generated by the fashion industry, CC does not seem to have taken deep root in this market unlike the 
INDEPENDENT JOURNAL OF MANAGEMENT \& PRODUCTION (IJM\&P)

http://www.ijmp.jor.br

v. 12, n. 2, March-April 2021

ISSN: 2236-269X

DOI: 10.14807/ijmp.v12i2.1313

other markets mentioned above. This can be partially explained by the fact that consumers are more willing to share less personal objects or services than the clothing or accessories we wear. According to research by Nielsen (2014), while 43\% of North Americans declared that they were willing to share goods or services with other people, only $22 \%$ or approximately half of them stated that they would be willing to share in cases where those objects were clothing or accessories.

Even though CC based businesses in the clothing industry seem to be lagging behind other industries, such as transportation, food, etc., previous research has offered a few CC models in the clothing industry. Park and Armstrong (2019) indicated that CC has thus far appeared in 4 different forms: short-term rentals, subscription-based rentals, swapping, and consignment.

However, in this present study, we will focus only on the first form, i.e., CC through short-term rental services where a repository or a large catalog of clothing and accessories is offered through a mobile app and/or a web-based service, whereby consumers can obtain access to wear these items in exchange for a rental fee, or on a subscription basis. Some of the advantages that these rental platforms provide the consumer are the sheer access they provide to a wider catalog of products and the opportunity to wear a greater variety of garments.

The ultimate goal of CC is to increase the accessibility to consumers, especially for those items, services or resources that entail high acquisition costs, high maintenance costs or high liabilities. This is possible due to a better redistribution of resources or better coordination of the acquisitions. On the other hand, one of the explicit downsides of these online fashion libraries is the need to renounce ownership of the products. Clearly, sharing in this form is not altruistic because economic compensation is sought by the suppliers (Belk, 2014; Hartl et al., 2016).

Although CC has been presented in very different forms and markets, there are some common bases. Botsman and Rogers (2010) differentiated 4 basic principles inherent to CC: critical mass, idling capacity, belief in the commons and trust between strangers. Later literature focused on studying the influence of the two common components introduced by Belk (2014): the temporary access nature or non-ownership aspect of the CC models and the technology (internet) reliance aspect made possible by the advent of Web 2.0.

In addition, it could be said that the non-ownership is a consequence of the implementation of these new technologies. In other words, ICT development facilitated consumers meeting their needs or gaining accessibility without the need for outright ownership (Hwang \& Griffiths, 2017). Similarly, the proliferation of mobile application use allows all 
DOI: 10.14807/ijmp.v12i2.1313

agents participating in the market to have an immediate and continuous exchange of information (Bardhi \& Eckhardt, 2012; Belk, 2014; Möhlmann, 2015; Hamari et al., 2016).

Examples of luxury apparel goods include special ceremonial dress, which many consumers will not wear after the event, clothing of a brand aimed at customers with high purchasing power, above average quality level clothing, a watch, a jewel or a purse. Additionally, these items tend not to be oriented towards large scale consumption. Given that extant literature on CC has not yet been extended into luxury apparel, this research takes the opportunity to assess the impacts of consumer personality traits on their attitude and intention toward CC of luxury apparel goods.

\subsection{Personality traits}

According to Rallapalli et al. (1994), different personality traits have an influence on the ethical predisposition of a consumer. In the same vein, Schiffman and Kanuk (2007) argued that personality traits affect consumers' predisposition toward different marketing strategies. There have been numerous authors who have studied different personality traits that positively or negatively affect consumer attitude or intention (Lindblom et al., 2018; Mainolfi, 2019).

However, it also should be noted that the impact of personality traits can change according to either the behavior in question, the behavioral context or other factors such as culture (Davidson et al., 2018). Due to the lack of previous study in the field of CC in the luxury apparel industry, we adopt the personality traits presented by Lang and Armstrong (2018) who investigated the impacts of need for uniqueness, fashion leadership and materialism on American women's adoption of clothing renting and swapping.

The need for uniqueness or need for differentiation in a fashion context is defined as "the need of pursuing of differentness relative to others through the acquisition, utilization and disposition of consumer goods” (Tian et al., 2001, p. 52). Lang and Armstrong (2018) stated that need for uniqueness works as a key driver that affects consumer clothing renting and swapping behavior.

Fashion leadership is defined as the need to be the first member of a social group to know about the latest trend in the market and the first to adopt it (Goldsmith et al., 1996; Gutman \& Mills, 1982; Polegato \& Wall, 1980). Lang and Armstrong (2015) determined that fashion leadership has a strong positive impact on consumer clothing renting and swapping behavior. Materialism refers to the importance that consumers attach to their belongings.

The storing of these belongings is considered as a life goal for some consumers (Richins \& Dawson, 1992). Previous fashion-related research shows that materialism values are 
DOI: 10.14807/ijmp.v12i2.1313

positively related to clothing involvement (Goldsmith et al., 2012) and intention to purchase luxury products (Mainolfi, 2019). A possessive consumer, on the other hand, prefers ownership over renting, leasing, or borrowing Belk (1984), all of the typical ways in which CC is implemented. In addition, Ozanne and Ballantine (2010) found that market avoiders are consumers who are interested in sharing and hence possess the least materialistic characteristics.

However, some studies including Lang and Armstrong (2018) found that materialism has a negative influence on consumer intention toward clothing renting and swapping. While most studies found either a positive or a negative relationship between materialism and consumer attitude and intention, other studies including Johnson et al. (2016) found no significant relationships between materialism and intention toward the behavior in question.

\subsection{Reconceptualization and hypotheses}

The theory of planned behavior (TPB) is commonly used to indicate the factors that shape certain behaviors, especially in the consumer behavior field (Taylor \& Todd, 1995). The TPB is an improvement on the theory of reasoned action (TRA) covering both individual and social factors (Ajzen, 1991).

However, in this study we have focused only on the former. Lang and Armstrong (2018) built a theoretical framework on the basis of TPB for investigating impacts of consumer personality traits on their intention to adopt clothing renting and swapping. As mentioned earlier, this study draws its framework on the work of Lang and Armstrong (2018) and extends it to luxury fashion apparel. Our conceptual framework (Figure 1) explores impacts of need for uniqueness, fashion leadership and materialism on middle-aged women's attitude and intention toward CC of luxury apparel goods. 
DOI: $10.14807 /$ ijmp.v12i2.1313

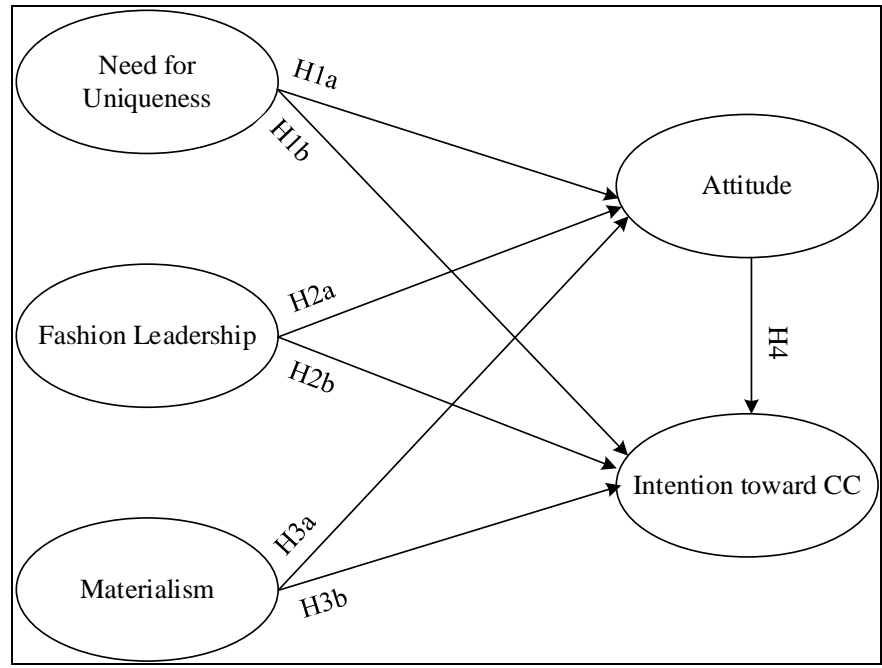

Figure 1: Research Framework

\subsubsection{Need for uniqueness}

Need for uniqueness was not studied in the primary literature on the factors that affect consumer behavior towards CC but was included in studies of the sharing economies in the fashion industry. This factor was introduced because consumers use fashion to reaffirm their identity and to differentiate themselves from other members of their community (Gentina et al., 2014).

As such, "differentiation" takes on more importance in the fashion market than in any other market where the CC business model is applied. When focusing on the luxury market, need for uniqueness refers to the user's perception of the value of luxury brands as a social classification and as a strengthening of personal image and social status (Wiedmann et al., 2009).

Lang and Armstrong (2018), in the clothing renting and swapping context, found that need for uniqueness significantly affects consumer CC behavior. We believe that through the use of CC, consumers have greater access to goods with high intrinsic attributes that can satisfy their need for uniqueness. Therefore, the following hypotheses are formulated:

- H1a: Need for uniqueness is positively related to consumer attitude towards CC of luxury apparel goods.

- H1b: Need for uniqueness is positively related to consumer intention towards CC of luxury apparel goods.

\subsubsection{Fashion leadership}

Fashion leaders are those consumers who adopt a fashion at the earliest stages of its market cycle and are therefore seen as creditable for spreading awareness and creating diffusion 
DOI: 10.14807/ijmp.v12i2.1313

of a style or trend (Wiedmann et al., 2012; Shephard et al., 2014). Prior literature depicts that the motivation of fashion leaders to purchase new fashion is related to social and psychological factors that are linked with their expression of self-image. This behavior is also influenced by various factors such as gender, age, social status, occupation, personality, and behavioral expectations (Goldsmith et al., 1991).

Kang and Park-Poaps (2010) found that fashion leadership is associated with the utilitarian/hedonic motivations and the innovativeness of consumers. Fashion leaders may also buy newly launched fashion products due to the excitement of affordability and the enjoyment that these products bring (Schrank \& Gilmore, 1973). Recent relevant literature has proven that fashion leadership or need for fashion positively influences the intention towards the collaborative economy in the general apparel industry (Lang \& Armstrong, 2015). Therefore, the following hypotheses are formulated:

- H2a: Fashion leadership is positively related to consumer attitude towards CC of luxury apparel goods.

- H2b: Fashion leadership is positively related to consumer intention towards CC of luxury apparel goods.

\subsubsection{Materialism}

Materialism, in general, depicts consumers' perspectives regarding the role of possessions and their importance in their life (Lang \& Armstrong, 2018). The hoarding of such material possessions can be a life goal for certain people (Richins \& Dawson, 1992). Belk (1984) distinguish 2 sub-dimensions of materialism: possessiveness and non-generosity. He suggested that a possessive person tends to prefer ownership over renting, leasing, or borrowing which are some ways that determine collaborative consumption.

Furthermore, Ozanne and Ballantine (2010)_obtained as a result of their study that consumers willing to participate in sharing activities have a low materialistic score. According to different authors, materialism works as a deterrent that leads consumers to have a negative attitude towards the use of collaborative economics (Moeller \& Wittkowski, 2010; Lindblom et al., 2018).

Akbar et al. (2016, p. 8) stated that '[materialism] is the key inhibitor for the acceptance of sharing business models'. In addition, Lang and Armstrong (2018) determined that materialism has a negative effect on the use of collaborative consumption in the fashion 
DOI: 10.14807/ijmp.v12i2.1313

industry, either in the form of clothing swapping or renting. Therefore, the following hypotheses are formulated:

- H3a: Materialism is negatively related to consumer attitude towards CC of luxury apparel goods.

- H3b: Materialism is negatively related to consumer intention towards CC of luxury apparel goods.

As mentioned earlier, the research model in the current research is based on Ajzen's (1991) TPB. When applying TPB, previous researchers found that consumer attitude, subjective norms, and perceived behavioral control affect behavioral intention. However, the focus of this study is the impact of personality traits on consumer attitude and intention toward CC of luxury apparel goods therefore factors such as subjective norms, and perceived behavioral control were not included in our research model. Therefore, the following hypothesis is formulated:

- H4: Consumer attitude towards CC is positively related to their intention towards CC of luxury apparel goods.

\section{METHODOLOGY}

\subsection{Data collection process, questionnaire instrument and sample description}

A pool of items was first developed from extant literature followed by development of a preliminary questionnaire. The questionnaire was then improved with the help of academic experts and translated into Spanish and back-translated into English for testing translational equivalence. A pilot survey was conducted with the help of 25 middle-aged Spanish women. The questionnaire items were further refined according to their feedback. The questionnaire was again reviewed by academic experts.

Next, a main test with 200 surveys was carried out on a one-to-one basis with middleaged Spanish women. Of the 200 surveys conducted, 123 were retained in the final sample with 43 being discarded because the respondents did not fit the targeted age range of 35 to 65 years of age and a further 34 were removed because they were incomplete.

The questionnaire was divided into three parts. Definitions of key terms such as CC and luxury apparel goods along with examples of each were provided in the first part of the questionnaire. The second part of the questionnaire consisted of general information questions identifying the demographic variables such as gender, age, level of education, occupation, 
INDEPENDENT JOURNAL OF MANAGEMENT \& PRODUCTION (IJM\&P)

http://www.ijmp.jor.br

v. 12, n. 2, March-April 2021

ISSN: 2236-269X

DOI: 10.14807/ijmp.v12i2.1313

marital status and annual family income. Furthermore, information was required about average use per month of social media, the average number of online purchases per month and the level of familiarity with mobile technologies. Finally, CC usage experience was also sought. Table 1 shows the respondents demographic details. The third part, i.e., the main survey consisted of items corresponding to the constructs used. A 5-point Likert scale with 1 corresponding to strongly disagree, 2 to disagree, 3 to neutral, 4 to agree and 5 to strongly agree was employed.

In line with previous research pertinent to luxury apparel, this study focused only on female subjects. Moreover, previous research indicates that women in the age group of 35-49 are one of the prominent users of luxury apparel compared to younger consumers (DUBOIS \& LAURENTS, 1993). Therefore, the current study does not focus on young women, but middleaged women.

Table 1: Demographics

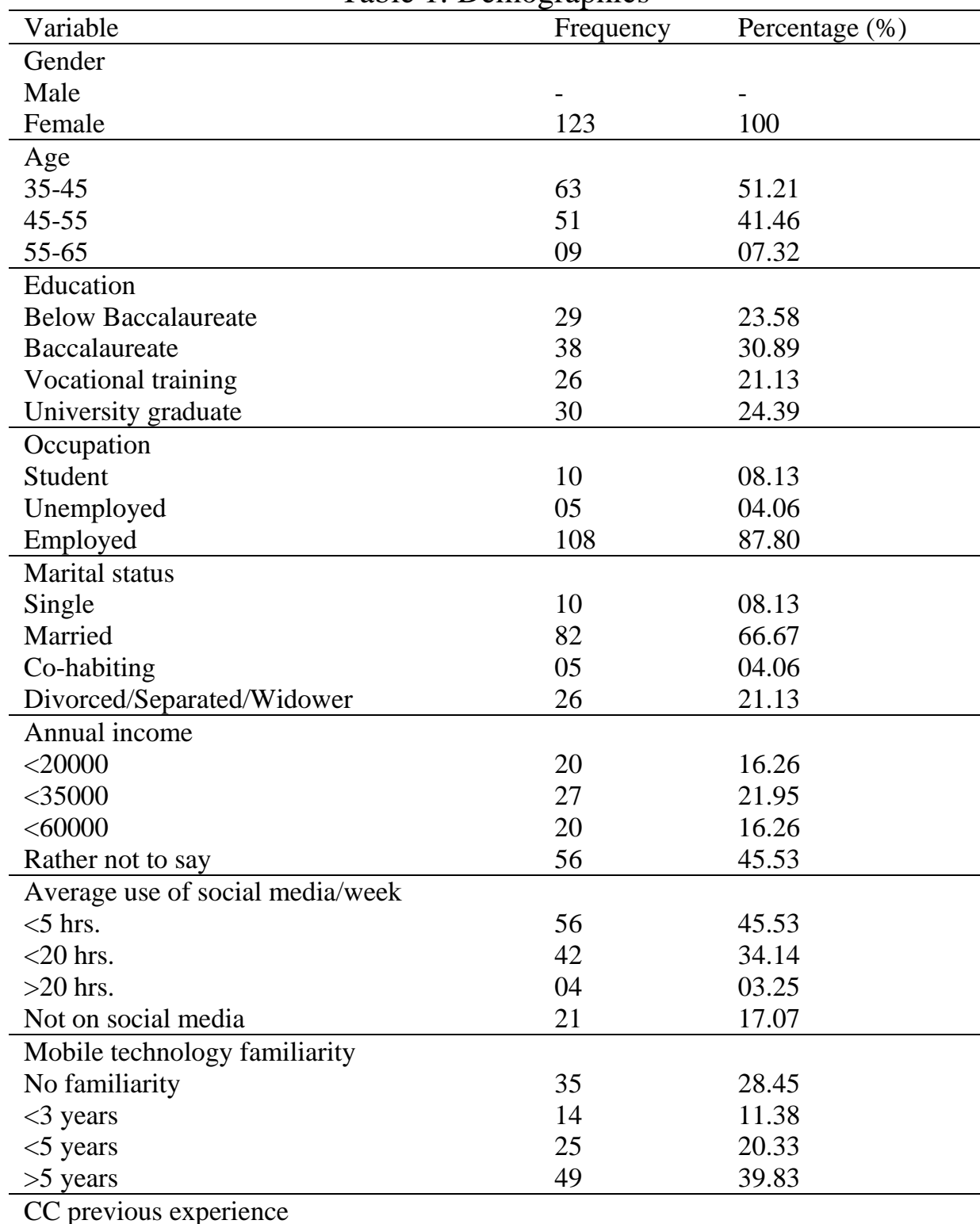


ISSN: 2236-269X

DOI: $10.14807 /$ ijmp.v12i2.1313

\begin{tabular}{lll}
\hline Car/food/apartment sharing & 24 & 19.51 \\
Multimedia repositories & 04 & 03.25 \\
Second-hand market & 06 & 04.87 \\
No experience & 89 & 72.36 \\
\hline
\end{tabular}

The data were collected from a single questionnaire therefore it was necessary to test common method variance. In doing so, this study uses popular approaches such as co-variance method, and PLS-SEM specific full collinearity assessment approach. According to previous relevant research (Bagozzi et al., 1991; Tehseen et al., 2017), the threat of common method variance is existent when inter-construct coefficients exceed a value of 0.9. All of the interconstruct coefficients are lower than 0.9 (Table 3). Further, this study follows Kock (2015) regarding the assessment of common method bias and full collinearity in PLS-SEM at the factor level. Accordingly, variance inflection factors (VIF) of all latent variables were generated using SmartPLS version 3.3.2. VIF values were lower than the cut off value of 3.3 as suggested by Kock (2015) indicating that the model is not affected by multi-collinearity or common method variance.

\subsection{Result}

The hypotheses were tested employing PLS-SEM analysis. Prior to testing the proposed hypotheses, a confirmatory factor analysis (CFA) was performed for testing reliability and validity of the measurement instrument. The results tabulated in Table 2 indicate that item factor loadings, composite reliability (CR), and Average variance extracted (AVE) exceed thresholds $0.5,0.7$ and 0.5 , respectively while table 3 shows that the square root of AVE is higher than inter-construct correlations. Overall, it satisfies both the reliability and validity criteria recommended in the previous research (FORNELL \& LARCKER, 1981). The hypothesized relationships in the proposed research framework were estimated through PLS based regression analysis using SmartPLS software. Bootstrap re-sampling method with a setting of 600 re-samples was used to examine the significance of the paths within the structural model. The structural model is presented below in Figure 2.

Table 2: Construct reliability and validity

\begin{tabular}{|c|l|c|}
\hline Construct & \multicolumn{1}{|c|}{ Item description } & $\begin{array}{c}\text { Factor } \\
\text { loading }\end{array}$ \\
\hline Materialism (MAT) (CR=0.88; AVE=0.66) (Lang and Armstrong, 2018) & 0.86 \\
\hline MAT1 & I admire people who wear luxurious items, especially clothes or accessories. & 0.85 \\
\hline MAT2 & The things I wear say a lot about how well I'm doing in life. & 0.79 \\
\hline MAT3 & I like to wear things that impress people. & 0.73 \\
\hline MAT4 & I want a lot of luxury in my life & 0.91
\end{tabular}


INDEPENDENT JOURNAL OF MANAGEMENT \& PRODUCTION (IJM\&P)

http://www.ijmp.jor.br

v. 12, n. 2, March-April 2021

ISSN: 2236-269X

DOI: $10.14807 /$ ijmp.v12i2.1313

\begin{tabular}{|c|l|c|}
\hline FLP2 & I am usually the first one to know the latest fashion trends. & 0.94 \\
\hline FLP3 & $\begin{array}{l}\text { I am the first to try new fashion therefore, many people regard me as a } \\
\text { fashion leader. }\end{array}$ & 0.90 \\
\hline Need for uniqueness (NFU)(CR=0.93;AVE=0.81) (Bian and Forsythe, 2012); (Lang and Armstrong, 2018) \\
\hline NFU1 & $\begin{array}{l}\text { I often lookout for new products or brands that add-up to my personal } \\
\text { uniqueness. }\end{array}$ & 0.86 \\
\hline NFU2 & I dislike brands or products that are purchased by everyone. & 0.93 \\
\hline NFU3 & I often try to avoid products or brands that are bought by general population. & 0.91 \\
\hline Attitude (ATT) & (CR=0.94; AVE=0.84) (Sung et al., 2018); (Hamari et al., 2016) & 0.90 \\
\hline ATT1 & $\begin{array}{l}\text { All things considered, I find participating in CC for luxury clothing and } \\
\text { accessories to be a wise move. }\end{array}$ & 0.94 \\
\hline ATT2 & $\begin{array}{l}\text { All things considered, I think participating in CC for luxury clothing and } \\
\text { accessories to be a wise move. }\end{array}$ & 0.91 \\
\hline ATT3 & All things considered, I find CC is a positive thing. & 0.95 \\
\hline Intention to CC (INT) (CR=0.94; AVE=0.89) (Barnes and Mattson, 2017); (Hamari et al., 2016) \\
\hline INT1 & $\begin{array}{l}\text { In the future, I will consider to use CC to acquire luxury clothing or } \\
\text { accessories. }\end{array}$ & 0.93 \\
\hline INT2 & In the future, I intend to use CC to acquire luxury clothing or accessories. & 0 \\
\hline
\end{tabular}
Notes: AVE-Average variance extracted, CR-Composite reliability

Table 3: Inter-construct correlations

\begin{tabular}{|c|c|c|c|c|c|c|c|c|c|c|}
\hline & Mean & $\begin{array}{l}\mathrm{S} \\
\mathrm{D}\end{array}$ & $\begin{array}{c}\text { Cronbach's } \\
\text { alpha }\end{array}$ & AVE & $\sqrt{A V E}$ & MAT & FLP & NFU & ATT & INT \\
\hline MAT & 2.34 & $\begin{array}{l}1 . \\
33\end{array}$ & 0.83 & 0.66 & 0.81 & 1.00 & & & & \\
\hline FLP & 1.77 & $\begin{array}{l}1 . \\
10\end{array}$ & 0.90 & 0.84 & 0.91 & 0.62 & 1.00 & & & \\
\hline $\mathrm{NFU}$ & 2.90 & $\begin{array}{l}1 . \\
26\end{array}$ & 0.88 & 0.81 & 0.90 & 0.60 & 0.59 & 1.00 & & \\
\hline ATT & 2.72 & $\begin{array}{l}1 . \\
29\end{array}$ & 0.91 & 0.84 & 0.91 & 0.47 & 0.52 & 0.59 & 1.00 & \\
\hline INT & 2.19 & $\begin{array}{l}1 . \\
26\end{array}$ & 0.87 & 0.89 & 0.94 & 0.51 & 0.64 & 0.58 & 0.75 & 1.00 \\
\hline
\end{tabular}

Notes: AVE-Average variance extracted, SD-Standard deviation, MAT-Materialism,

FLP-Fashion leadership, NFU-Need for uniqueness, ATT-Attitude, INT-Intention

Results clearly show that personality traits such as consumers need for uniqueness and fashion leadership are positively related to consumer attitude toward CC of luxury apparel goods which in turn positively affects consumer intention toward CC of luxury apparel goods. It can also be seen from Figure 2 that fashion leadership directly and meaningfully impacts consumer intentions toward CC of luxury apparel goods. Interestingly, consumer materialism has neither a significant impact on consumer attitude nor intention. Finally, need for uniqueness was found to have no significant impact on consumer intention toward CC of luxury apparel goods. With this, hypotheses $\mathrm{H} 1 \mathrm{a}, \mathrm{H} 2 \mathrm{a}, \mathrm{H} 2 \mathrm{~b}$ and $\mathrm{H} 4$ were supported (solid line) while hypotheses H1b, H3a and H3b rejected (dotted line). 
DOI: $10.14807 /$ ijmp.v12i2.1313

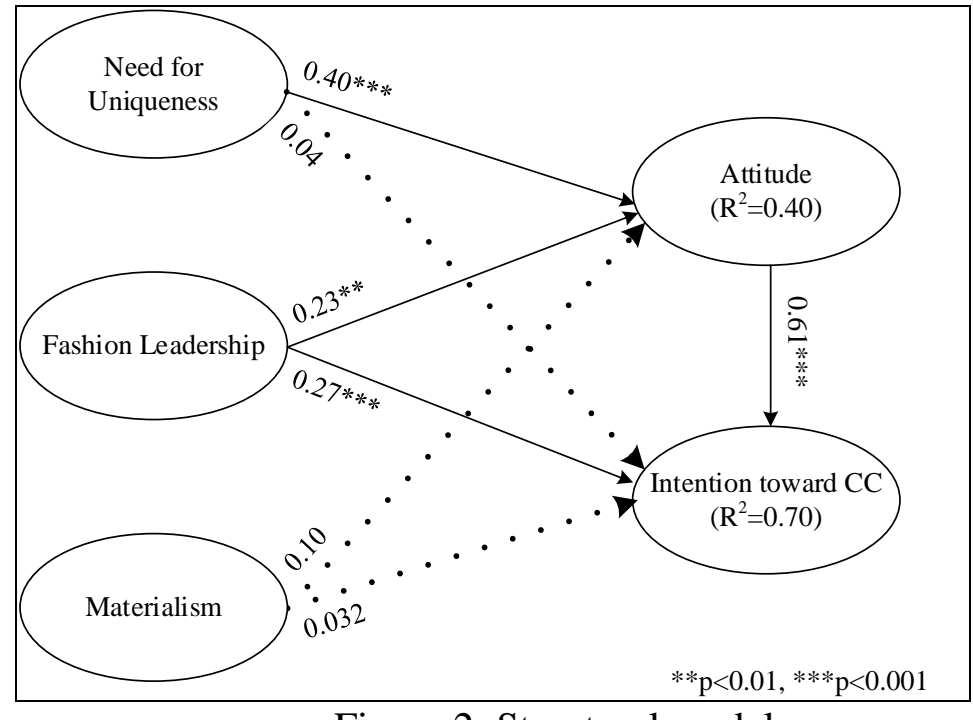

Figure 2: Structural model

\section{DISCUSSION}

With the advances in mobile technology, CC based business models have gained rapid popularity. Despite the rapid proliferation of fashion clothing libraries, extant literature on CC pertaining to luxury apparel fashion goods is very limited. Previous research fails to examine CC in middle-aged women. In order to understand the impacts of middle-aged women's personality traits on their attitude and intention toward CC of luxury apparel goods, this research develops a research model, collects data through questionnaire survey and analyzes hypothesized relationships using PLS-SEM approach.

The results indicate that need for uniqueness positively affects attitudes but not intention toward CC. However, we found an indirect meaningful effect of need for uniqueness on intention toward CC. This result is partially consistent with previous research (Lang \& Armstrong, 2018; Asshidin et al., 2016). This finding indicates that middle-aged women having a higher level of need for uniqueness are more inclined towards CC of luxury apparel goods. This is perhaps because they are likely to be disinterested in brands or products that are purchased by the masses so CC of luxury apparel goods enables them to stand-out from the crowd. Another probable reason is their attempt to maintain their social status for which differentiation is necessary.

We found fashion leadership to be the most critical personality trait affecting both consumer attitude and intention toward CC of luxury apparel goods. This result was consistent with Lang and Armstrong (2015). This finding reinforces that consumers with high fashion leadership are the first to use new luxury apparel goods. In general, 'fashion-oriented' consumers are seen as consumers who are open to new ideas, have a higher willingness to 
DOI: 10.14807/ijmp.v12i2.1313

accept new things and thus play a key role in fashion diffusion (Lang \& Armstrong, 2015; 2018). Hansen (2017) stated that middle-aged women embrace recent fashion trends in order to have a modern, professional and classy appearance therefore they are likely to play a leading role in accepting new trends in fashion apparel.

The results of the study further indicate that the relationships between materialism and both attitude and intention are not significant. Recent consumer behavior research also found no significant relationship between materialism and consumer sharing intention (Helm \& Subramaniam, 2019). Moreover, previous research pertinent to consumer apparel also offers a consistent finding (JOHNSON et al., 2016). However, our finding is inconsistent with Lang and Armstrong (2018) and Lindblom et al. (2018).

Our result indicates that materialistic consumers do not yet deem CC as either favorable or unfavorable in terms of luxury apparel goods. This is perhaps because of the contemporary status of CC based business models, lack of consumer curiosity in CC among middle-aged women and their unwillingness to forfeit transfer of ownership. It also should be noted that the behavioral outcome associated with consumer materialism varies across cultures despite being one of the universal personality traits of consumers (Davidson et al., 2018).

\section{CONCLUSION}

\subsection{Research conclusions}

The primary objective of this study was to investigate impacts of personality traits on consumer attitude and intention toward CC of luxury apparel goods among middle-aged women. In order to address the research objective a research framework hypothesizing logical relationships was proposed. Further, data collected through a questionnaire survey was analyzed with PLS-SEM technique. Since it significantly affected both consumer attitude and intention toward CC, fashion leadership was found to be the most critical personality trait followed by consumer need for uniqueness.

Consumer materialism was found to have no significant impact on either consumer attitude or intention toward CC of luxury apparel goods. Consumer attitude was found to have a significant direct impact on consumer intention toward CC. The results suggest that CC fashion marketers need to concentrate on critical personality traits such as fashion leadership while developing strategies for the middle-aged female segment of the market. The findings of this study should be used with caution because some personality traits such as materialism are subjective and can be affected by different age groups and cultures. 
DOI: $10.14807 /$ ijmp.v12i2.1313

\subsection{Research implications}

This study has several managerial implications. Considering the importance of key personality traits such as fashion leadership and need for uniqueness, managers should design business models that are capable of attracting the attention of the appropriate target consumer. This would avoid wasting resources on marketing strategies that attempt to attract customers having no inclination towards CC of luxury apparel goods. In other words, CC fashion outlets and advertisers need to understand the exact personality traits that impact intention towards CC usage among their various target markets. As well as this, industry players might be well served if they focus their efforts not just directly on intention towards CC but rather on the broader attitudes toward CC usage amongst their potential customers.

The study concludes that the most important factor to take into account when applying CC in an online rental model is fashion leadership. One of the greatest added values that such a platform should provide is access to the largest possible number of catalog items. These items should also comprise of the latest luxury fashion offerings due to the influence of fashion leadership on attitude and intention.

In addition, this work also has academic implications because it generates a starting point in the study of CC in the luxury fashion context. We delve into the study of different personality traits that allow us to predict the intention towards use and the attitude towards CC.

\subsection{Research limitations and future scope}

It should be noted that this current study is not without limitations. First, this study assesses the impact of only three personality traits: materialism, need for uniqueness and fashion leadership. Future work should consider other types of consumer personality traits for more comprehensive in-depth research. It is also recommended to explore social and technology traits and their impacts on CC. Second, the current study only investigates behavioral intention, but future research can explore actual behavior. Finally, this study collects data exclusively from a single country. It would be valuable to perform comparative research across several populations.

\section{REFERENCES}

Ajzen, I. (1991). The theory of planned behavior. Organizational Behavior and Human Decision Processes, 50(2), 179-211.

Akbar, P. M. (2016). When do materialistic consumers join commercial sharing systems.

Journal of Business Research, 69(10), 4215-4224. 
Amaro, S., \& Andreu, L. (2019). Millenials' intentions to book on Airbnb. Current Issues in Tourism, 22(18), 2284-2298.

Asshidin, N. H. N., Abidin, N., \& Borhan, H. B. (2016). Consumer attitude and uniqueness towards international products. Procedia Economics and Finance, 35, 632-638.

Bagozzi, R. P., Yi, Y., \& Phillips, L. W. (1991). Assessing construct validity in organizational research. Administrative Science Quarterly, 36(3), 421-458.

Bardhi, F., \& Eckhardt, G. M. (2012). Access-based consumption: The case of car sharing. Journal of Consumer Research, 39(4), 881-898.

Barnes, S. J., \& Mattson, J. (2017). Understanding collaborative consumption: Test of a theoretical model. Technological Forecasting and Social Change, 118, 281-292.

Barnes, S. J., \& Mattsson, J. (2016). Understanding current and future issues in collaborative consumption: A four-stage Delphi study. Technological Forecasting and Social Change, 104, 200-211.

Bearden, W. O., \& Etzel, M. J. (1982). Reference group influence on product and brand purchase decisions. Journal of Consumer Research, 9(2), 183-194.

Belk, R. (1984). Three scales to measure constructs related to materialism: Reliability, validity, and relationships to measures of happiness. ACR Advances in Consumer Research, 11, 291-297.

Belk, R. (2014). You are what you can access: Sharing and collaborative consumption online. Journal of Business Research, 67, 1595-1600.

Benoit, S. B., Baker, T. L., Bolton, R. N., Thorsten, G., \& Kandampully, J. (2017). A triadic framework for collaborative consumption (CC).: Motives, activities and resources \& capabilities of actors. Journal of Business Research, 79, 2019-227.

Bian, Q., \& Forsythe, S. (2012). Purchase intention for luxury brands: A cross cultural comparison. Journal of Business Research, 65(10), 1443-1451.

Böcker, L., \& Meelen, T. (2017). Sharing for people, planet or profit? Analysing motivations for intended sharing economy participation. Environmental Innovation and Societal Transitions, 23, 28-39.

Botsman, R., \& Rogers, R. (2010). What's mine is yours: The rise of collaborative consumption, 1 ed, New York: HarperCollin publishers.

Davidson, A., Habibi, M. R., \& Laroche, M. (2018). Materialism and the sharing economy: A cross-cultural study of American and Indian consumers. Journal of Business Research, 82, 364-372.

Dubois, B. L., \& Laurents, G. (1993). Is there a Euro consumer for luxury good? European Advances in Consumer Research, 1, 58-89.

Ertz, M., Durif, F., \& Arcand, M. (2016). Collaborative consumption or the rise of the twosided consumer. International Journal of Business and Management, 4(6), 195-209.

Felson, M., \&Spaeth, J. L. (1978). Community structure and collaborative consumption. American Behavioral Scientist, 21(4), 614-624.

Fornell, C. D., \&Larcker, D. F. (1981). Evaluating structural equation models with unobservable variables and measurement error. Journal of Marketing Research, 18, 39-50. 
DOI: 10.14807/ijmp.v12i2.1313

Gbadamosi, A. (2013). Principles of marketing: A value-based approach, London: Palgrave Macmillan.

Gentina, E., Butori, R., \& Heath, T. B. (2014). Unique but integrated: The role of individuation and assimilation processes in teen opinion leadership. Journal of Business Research, 67(2), 83-91.

Goldsmith, R. E., Heitmeyer, J. R., \& Freiden, J. B. (1991). Social values and fashion leadership. Clothing and Textiles Research Journal, 10(1), 37-45.

Goldsmith, R. E., Flynn, L. R., \& Clark, R. A. (2012). Materialistic, brand engaged and status consuming consumers and clothing behaviors. Journal of Fashion Marketing and Management, 16(1), 102-119.

Goldsmith, R. E., Flynn, L. R., \& Moore, M. A. (1996). The self-concept of Fashion Leaders. Clothing and Textiles Research Journal, 14(4), 242-248.

Görög, G. (2018). The definitions of sharing economy: A systematic literature review. Management, 13(2), 175-189.

Gutman, J., \& Mills, M. K. (1982). Fashion life style, selfconcept, shopping orientation, and store patronage: An integrative analysis. Journal of Retailing, 58, 64-86.

Hamari, J. S., Sjöklint, M., \& Ukkonen, A. (2016). The sharing economy: Why people participate in collaborative consumption. Journal of the Association for Information Science and Technology, 67(9), 2047-2059.

Hansen, V. (2017). 8 Wardrobe Essentials for Women In Leadership. Available: https://www.huffpost.com/entry/8-wardrobe-essentials-for_b_8694090

Hartl, B. H., Hofmann, E., \& Kirchler, E. (2016). Do we need rules for “what's mine is yours"? Governance in collaborative consumption communities. Journal of Business Research, 69, 2756-2763.

Hawley, A. (1950). Human ecology: A theory of community structure, 1 ed. New York: Ronald Press Co.

Helm, S., \& Subramaniam, B. (2019). Exploring Socio-Cognitive Mindfulness in the Context of Sustainable Consumption. Sustainability, 11(13), 3692.

Hwang, F., \& Griffiths, J. (2017). Share more, drive less: Millennials value perception and behavioral intent in using collaborative consumption services. Journal of Consumer Marketing, 34(2), 132-146.

Johnson, K. K. P., Mum, J. M., \& Chae, Y. (2016). Antecedents to Internet use to collaboratively consume apparel. Journal of Fashion Marketing and Management, 20(4), 370-382.

Kang, J., \& Park-Poaps, H. (2010). Hedonic and utilitarian shopping motivations of fashion leadership. Journal of Fashion Marketing and Management, 14(2), 312-328.

Kim, J., Yoon, Y., \& Zo, H. (2015). Why People Participate in the Sharing Economy: A Social Exchange Perspective. In: Pacific Asia Conference on Information Systems, 76, Singapore, Proceedings PACIS, 2015. Available: https://aisel.aisnet.org/pacis2015/76/

Kock, N. (2015). Common method bias in PLS-SEM: A full collinearity assessment approach. International Journal of e-Collaboration, 11(4), 1-10.

Lang, C., \& Armstrong, C. M. J. (2015). What's Mine is Yours: Does Fashion Leadership Impede Clothing Renting and Swapping?. In: INTERNATIONAL TEXTILE and APPAREL 
DOI: 10.14807/ijmp.v12i2.1313

ASSOCIATION ANNUAL CONFERENCE, 84, Santa Fe, Proceedings ITAA, 2015. Available:

https://lib.dr.iastate.edu/cgi/viewcontent.cgi?article=1344\&context=itaa_proceedings

Lang, C., \& Armstrong, C. M. J. (2018). Collaborative consumption: The influence of fashion leadership, need for uniqueness, and materialism on female consumers' adoption of clothing renting and swapping. Sustainable Production and Consumption, 1(3), 37-47.

Lindblom, A. L., Lindblom, T., \& Wechtler, H. (2018). Collaborative consumption as C2C trading: Analyzing the effects of T materialism and price consciousness. Journal of Retailing and Consumer Services, 44, 244-252.

Mainolfi, G. (2019). Exploring materialistic bandwagon behaviour in online fashion consumption: A survey of Chinese luxury consumers. Journal of Business Research, Article in press.

Moeller, S., \& Wittkowski, K. (2010). The burdens of ownership: Reasons for preferring renting. Journal of Service Theory and Practice, 20(2), 176-191.

Möhlmann, M. (2015). Collaborative consumption: determinants of satisfaction and the likelihood of using a sharing economy option again. Journal of Consumer Behavior, 14(3), 193-207.

Nielsen (2014). Is sharing the new buying? Reputation and trust are emerging as new currencies. New York, NY: Nielsen. Available: https://www.nielsen.com/wpcontent/uploads/sites/3/2019/04/global-share-community-report-may-2014.pdf.

Ozanne, L. L., \& Ballantine, P. W. (2010). Sharing as a form of anti-consumption? An examination of toy library users. Journal of Consumer Behaviour, 9(6), 485-498.

Palos-Sánchez, P. R., \& Correia, M. (2018). The collaborative economy based analysis of demand: Study of airbnb case in Spain and Portugal. Journal of Theoretical and Applied Electronic Commerce Research, 13(3), 85-98.

Park, H., \& Armstrong, J. (2019). Will "no-ownsership" work for apparel? Implications for apparel retailers. Journal of Retailing and Consumer Services, 47, 66-73.

Polegato, R., \& Wall, M. (1980). Information seeking by fashion opinion leaders and followers. Home Economics Research Journal, 8, 327-338.

Raja, J. I., \& Malik, J. A. (2014). Personality dimensions and decision making: exploring consumers’ shopping styles. Journal of Behavioural Sciences, 24(2), 18-33.

Rallapalli, K. C., Vitell, S. J., Wiebe, F. A., \& Barnes, J. H. (1994). Consumer ethical beliefs and personality traits: an exploratory analysis. Journal of Business Ethics, 31(1), 209-219.

Richins, M. L., \& Dawson, S. (1992). A consumer values orientation for materialism and its meassurement: Scale development and validation. Journal of Consumer Research, 19), 303-316.

Santoso, A. S., \& Erdaka, A. (2015). Customer loyalty in collaborative consumption model: Empirical study of CRM for product-service system-based e-commerce in Indonesia. Procedia Computer Science, 72(1), 543-551.

Saxena, R. (2009). Marketing management, 4 ed. New Delhi: Tata McGraw-Hill.

Schaefers, T. L. K., Lawson, S., \& Kukar-Kinney, M. (2015). How the burdens of ownership promote usage of access-based services. Marketing Letters, 27, 569-577. 
Schiffman, L., \& Kanuk, L. (2007). Consumer Behavior. 9 ed, Saddle River, NJ: Pearson Education, Inc.

Schor, J., \& Fitzmaurice, C. J. (2015). Collaborating and connecting: The emergence of sharing economy, in Reisch, L. A., Thøgersen, J. (Eds)., Handbook on Research on Sustainable Consumption, Cheltenham, UK: Edward Elgar Publishing), 410-425.

Schrank, H. L., \& Gilmore, D. L. (1973). Correlates of fashion leadership: Implications for fashion process theory. Sociological Quarterly, 14(4), 534-543.

Shephard, A. J., Kinley, T. R., \& Josiam, B. M. (2014). Fashion leadership, shopping enjoyment, and gender: Hispanic versus, Caucasian consumers' shopping preferences. Journal of Retailing and Consumer Services, 21(3), 277-283.

So, K. K., Oh, H., \& Min, S. (2018). Motivations and constraints of Airbnb consumers: Findings from a mixed-methods approach. Tourism Management, 67, 224-236.

Sung, E., Kim, H., \& Lee, D. (2018). Why do people consume and provide sharing economy accommodation?-A sustainability perspective. Sustainability, 10(6), 2072.

Taylor, S., \& Todd, P. (1995). Understanding household garbage reduction behavior: A test of an integrated model. Journal of Public Policy \& Marketing, 14(2), 192-204.

Tehseen, S., Ramayah, T., \& Sajilan, S. (2017). Testing and controlling for common method variance: A review of available methods. Journal of Management Sciences, 4(2), 142-168.

Tian, K. T., Bearden, W. O., \& Hunter, G. L. (2001). Consumers' need for uniqueness: scale development and validation. Journal of Consumer Research, 28(1), 50-66.

Tussyadiah, I. (2015). An exploratory study on drivers and deterrents of collaborative consumption in travel, in: Tussyadiah, I., Inversini, A. (Eds)., Information and

Communication Technologies in Tourism, Lugano, Springer, 817- 830.

Wiedmann, K. P., Hennigs, N., \& Langner, S. (2010). Spreading the word of fashion: Identifying social influencers in fashion marketing. Journal of Global Fashion Marketing, 1(3), 142-153.

Wiedmann, K. P., Hennigs, N., \& Siebels, A. (2009). Value-based segmentation of luxury consumption behavior. Psychology \& Marketing, 26(7), 625-651. 